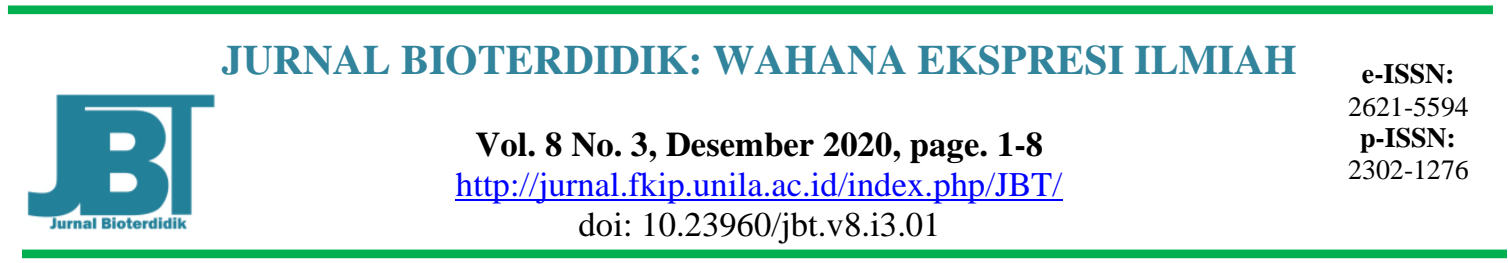

\title{
Pengaruh Pembelajaran Pengetahuan Pencemaran Secara Online Terhadap Sikap Peduli Lingkungan Siswa SMP Pada Heritage TNBBS Di Ulubelu
}

\author{
Septi Arlistiani* , Arwin Surbakti, Ismi Rakhmawati \\ Pendidikan Biologi, Fakultas Keguruan dan Ilmu Pendidikan, Universitas Lampung, Jl. Prof. Dr. \\ Soemantri Brojonegoro No. 1 Bandar Lampung, Indonesia \\ *e-mail: septiarlistiani03892@gmail.com
}

\begin{abstract}
The Influence Of Pollution Knowledge Learning By Online To Students' Environmental Care Attitude On The TNBBS Heritage In Ulubelu. This study aims to determine the influence of environmental pollution knowledge learning by online to care attitude on the TNBBS heritage in SMP Negeri 1 Ulubelu and understand which dimension of attitude was the most controlled by students to increase caring attitude TNBBS heritage. The design of this study was quantitatif descriptive. The samples in this study were a students of class VII-1, VII-2, and VII-3 with the totaling 50 people of the 93 students dan was determine through purposive sampling technique. The results showed that has the influence significant the online based environmental pollution knowledge learning to care attitude on the TNBBS heritage in SMP Negeri 1 Ulubelu. The demension of attitude was the most controlled by students to increase caring attitude TNBBS heritage was affection dimension with 35,38\% percent.
\end{abstract}

Keywords: enviromental pollution knowledge learning, care attitude on heritage, $T N B B S$

\begin{abstract}
Abstrak: Pengaruh Pembelajaran Pengetahuan Pencemaran Lingkungan Secara Online Terhadap Sikap Peduli Pada Heritage TNBBS Di SMP Negeri 1 Ulubelu. Penelitian ini bertujuan untuk mengetahui pengaruh pembelajaran pengetahuan pencemaran lingkungan secara online terhadap sikap peduli pada heritage TNBBS di SMPN 1 Ulubelu dan mengetahui dimensi manakah yang paling dikuasai oleh peserta didik untuk meningkatkan sikap peduli pada heritage TNBBS. Desain penelitian ini adalah deskriptif kuantitatif. Sampel dalam penelitian ini adalah peserta didik kelas VII1, VII-2, dan VII-3 dengan jumlah total 50 orang dari 93 peserta didik dan ditentukan melalui teknik purposive sampling. Hasil penelitian menunjukkan bahwa terdapat pengaruh yang signifikan pembelajaran online pengetahuan pencemaran lingkungan terhadap sikap peduli pada heritage TNBBS di SMP Negeri 1 Ulubelu. Dimensi yang paling dikuasai peserta didik dalam meningkatkan sikap peduli pada heritage TNBBS adalah dimensi "Afeksi" dengan presentase 35,38\%.
\end{abstract}

Kata kunci: pembelajaran pengetahuan pencemaran lingkungan, sikap peduli pada heritage, TNBBS. 


\section{PENDAHULUAN}

Heritage adalah warisan budaya yang perlu dilestarikan (Unesco, 1972). UNESCO memberikan definisi "heritage" sebagai warisan (budaya) masa lalu, yang seharusnya dilestarikan dari generasi ke generasi karena memiliki nilai-nilai luhur. Rekomendasi Piagam Pelestarian Pusaka Indonesia menyebutkan bahwa heritage sebagai pusaka (Entas dan Widiastiti, 2018: 14). Dalam buku yang berjudul Heritage Management, Interpretation, Identity, menjelaskan bahwa heritage sebagai segala sesuatu yang ingin diselamatkan orang, termasuk budaya material maupun alam (Howard, 2003). Salah satu heritage adalah Taman Nasional Bukit Barisan Selatan (TNBBS). Taman Nasional Bukit Barisan Selatan (TNBBS) adalah salah satu bagian dari hutan hujan tropis Sumatera yang diakui oleh UNESCO (United Nation Educational, Scientific, and Cultural Organization). Taman Nasional Bukit Barisan Selatan (TNBBS) memiliki keanekaragaman jenis hayati yang sangat tinggi, baik flora maupun fauna. Berdasarkan nilai konservasi yang tinggi tersebut UNESCO menetapkan kawasan ini menjadi Tapak Warisan Dunia Klaster Alam (Cluster Natural World Heritage Site) dengan nama The Tropical Rainforest Heritage of Sumatera pada bulan Juli Tahun 2004.

Taman Nasional Bukit Barisan Selatan tidak luput dari berbagai permasalahan. Mulai dari permasalahan keamanan kawasan, kelestarian sumber daya alam hayati, perambahan (encroachment), perburuan liar, penebangan liar (Illegal logging), konflik satwa dengan manusia, dan lain-lain (Deni, 2011: 10). Selain itu, masalah limbah sampah plastik di kawasan TNBBS juga sangat memprihatinkan. Sampah merupakan limbah akhir dari pemakaian manusia (Maruroh, 2018: 131) dan salah satu penyebab dari adanya pencemaran lingkungan. Banyaknya limbah sampah di kawasan TNBBS yang berasal dari wisatawan yang datang dan kendaraan yang melintasi jalan kawasan TNBBS.

Pada saat ini, permasalahan pencemaran lingkungan berkaitan dengan pemahaman, sikap dan perilaku dari masing-masing individu karena masing-masing individu mempunyai tingkat pengetahuan dan kesadaran lingkungan yang berbeda. Kurangnya sikap peduli lingkungan menyebabkan masalah pencemaran lingkungan berupa sampah diberbagai tempat. Untuk mewujudkan sikap peduli lingkungan khususnya di kawasan heritage (warisan) TNBBS harus ada upaya meningkatkan kepedulian masyarakat terhadap kawasan konservasi heritage TNBBS. Upaya tersebut akan sulit dilakukan apabila masyarakat tidak mengetahui pentingnya kawasan heritage TNBBS. Salah satu upaya yang dapat dilakukan yaitu melalui pendidikan formal, informal maupun nonformal.

Pada dasarnya, antara pengetahuan dan sikap memiliki hubungan satu sama lain. Penelitian terdahulu yang dilakukan pula oleh Fitria (2016: 50) di SMA Negeri di Kota Banda Aceh mengenai hubungan antara pengetahuan dengan sikap siswa terhadap pemanasan global menunjukkan bahwa terdapat hubungan yang kuat diantara kedua variabel. Jika dikaitkan dalam konteks ini maka seharusnya sikap peduli lingkungan dapat terbentuk ketika seseorang telah memiliki pengetahuan yang baik tentang lingkungan itu sendiri (Pertiwi, 2019: 4). Hal ini didukung oleh pernyataan Kellstedt (2008: 122) bahwa rendahnya rasa peduli masyarakat akan lingkungan, bukan karena masyarakat tidak peduli, melainkan karena masyarakat tidak cukup tahu tentang perubahan lingkungan yang terjadi di daerah tempat tinggalnya.

Perkembangan Teknologi informasi di era digital sangat berpengaruh terhadap sistem pembelajaran yang ada sekarang, terlebih adanya pandemi Covid-19 yang sedang 
melanda dunia. Pandemi Covid-19 adalah krisis kesehatan yang pertama dan terutama di dunia. Banyak negara memutuskan untuk menutup sekolah, perguruan tinggi dan univesitas. Pandemi tersebut menyebabkan pendidikan di Indonesia dilaksanakan di dalam jaringan atau secara daring di rumah (online). Pembelajaran daring (online $e$ learning) merupakan program penyelenggaraan kelas pembelajaran dalam jaringan untuk menjangkau kelompok target yang masif dan luas. Melalui jaringan, pembelajaran dapat diselenggarakan secara masif dengan peserta yang tidak terbatas (Bilfaqih dan Qomarudin, 2015: 1). Di dalam buku Salman Khan (2012) yang berjudul "The One World Schoolhouse", mengatakan "Pendidikan tidak terjadi di dalam ruang antara mulut guru dan telinga murid. Pendidikan terjadi di ruang di dalam otak masingmasing". Hal ini sejalan dengan teori pembelajaran konstruktivisme bahwa ilmu pengetahuan itu dibangun oleh murid melalui proses belajar, bukan dipindahkan dari guru ke murid.

Penelitian ini akan dilakukan di SMP Negeri 1 Ulubelu karena sekolah ini merupakan salah satu sekolah yang berada di sekitaran kawasan Taman Nasional Bukit Barisan Selatan (TNBBS). Berdasarkan hasil observasi mata pelajaran IPA kelas VII SMP Negeri 1 Ulubelu diketahui bahwa proses pembelajaran sudah menerapkan kurikulum 2013, melakukan pendekatan saintifik pada pembelajaran IPA dan telah menerapkan pembelajaran yang berpusat pada siswa (student center). Selain itu, menurut hasil observasi, guru belum mengetahui dan belum pernah mengukur sikap peduli heritage TNBBS pada siswa dan akibat adanya pademi Covid-19 yang terjadi maka penelitian ini dilakukan secara daring (pembelajaran online) pada siswa. Berdasarkan permasalahan tersebut maka peneliti tertarik untuk mengadakan penelitian yang berjudul "Pengaruh Pembelajaran Pengetahuan Pencemaran Lingkungan Secara Online Terhadap Sikap Peduli Pada Heritage TNBBS di SMP Negeri 1 Ulubelu".

\section{METODE}

Penelitian ini dilaksanakan di SMPN 1 Ulubelu yang beralamat di Jalan Raya Ngarip, Kecamatan Ulubelu, Kabupaten Tanggamus. Pada bulan Mei, semester genap 2019/ 2020. Populasi dalam penelitian ini adalah seluruh siswa kelas VII SMP Negeri 1 Ulubelu yang berjumlah 93 orang yang terbagi kedalam 3 kelas. Sampel yang digunakan pada penelitian ini adalah kelas VII-1, kelas VII- 2, dan kelas VII-3. Sampel diambil dari populasi dengan teknik purposive sampling dengan pertimbangan tertentu (Sugiyono, 2012: 68).

Penelitian ini menggunakan desain penelitian deskriptif kuantitatif noneksperimen. Prosedur penelitian ini dilakukan dalam tiga tahap yaitu tahap prapenelitian, tahap pelaksanaan penelitian, dan tahap akhir. Pada tahap prapenelitian kegiatan yang dilakukan yaitu membuat surat izin penelitian, melakukan observasi kesekolah, menetapkan sampel penelitian, menyusun instrumen tes pengetahuan materi pencemaran lingkungan dengan pilihan benar salah dan angket mengenai sikap peduli pada heritage TNBBS peserta didik dengan skala likert, melakukan uji coba instrumen dan menganalisis uji validitas, uji reabilitas, daya beda, dan tingkat kesukaran. Tahap pelaksanaan penelitian yang dilakukan yaitu membagikan soal-soal materi pencemaran lingkungan dan angket sikap peduli heritage TNBBS berbentuk googleform melalui grup whatsapp masing-masing kelas. Tahap akhir kegiatan yang dilakukan yaitu mengolah data hasil soal pengetahuan pencemaran lingkungan dan angket sikap peduli pada heritage TNBBS, menganalisis hasil pengolahan, dan memberikan kesimpulan. 
Pengetahuan pencemaran lingkungan merupakan data kuantitatif dengan pernyataan soal benar-salah sedangkan sikap peduli pada heritage TNBBS merupakan data kualitatif dengan instrumen berbentuk angket dan skala pengukuran menggunakan model skala likert. Uji yang digunakan pada penelitian ini adalah Uji Anova Satu Jalur (One-Way Anova Test). Sebelum menggunakan uji Anova dilakukan terlebih dahulu dilakukan uji prasyarat yaitu uji normalitas data menggunakan One-Sample Kolmogrov Smirnov Test dan uji homogenitas data menggunakan Levenes's Test pada taraf 5\% serta uji daya beda dan tingkat kesukaran yang diolah menggunakan SPPS 16.0 for windows.

\section{HASIL DAN PEMBAHASAN}

Pengaruh Pembelajaran Online Pengetahuan Pencemaran Lingkungan Terhadap Sikap Peduli Pada Heritage TNBBS. Pada penelitian ini memiliki dua variabel yaitu variabel bebas yaitu pembelajaran pengetahuan pencemaran lingkungan secara online dan variabel terikat yaitu sikap peduli pada heritage TNBBS. Berdasarkan hasil penelitian yang telah dilakukan di SMP Negeri 1 Ulubelu diperoleh hasil data nilai pengetahuan pencemaran lingkungan dan sikap peduli pada heritage TNBBS (Tabel 1).

Tabel 1. Hasil Nilai Pengetahuan Pencemaran Lingkungan dan Sikap Peduli Pada Heritage TNBBS

\begin{tabular}{lcc}
\hline Nilai & $\begin{array}{c}\text { Pengetahuan Pencemaran } \\
\text { Lingkungan }\end{array}$ & $\begin{array}{c}\text { Sikap Peduli Pada Heritage } \\
\text { TNBBS }\end{array}$ \\
\hline N & 50 & 50 \\
Mean & 78 & 83,31 \\
Sd & 11,93 & 8,63 \\
Max & 93,33 & 95,83 \\
Min & 50 & 66,66 \\
\hline
\end{tabular}

Keterangan: $\mathrm{n}=$ Jumlah peserta didik; Mean = Rata-rata; Sd = Standar deviasi; Nilai Max = Nilai tertinggi; Nilai Min = Nilai Terendah

Tabel 1 menunjukkan hasil nilai pengetahuan pencemaran lingkungan dan sikap peduli pada heritage TNBBS. Pada pencemaran lingkungan memiliki nilai rata-rata sebesar 78 sedangkan pada sikap peduli pada heritage TNBBS memiliki nilai rata-rata sebesar 83,31. Mata pelajaran IPA di SMP Negeri 1 Ulubelu memiliki KKM sebesar 71. Berdasarkan hasil nilai tersebut dapat dilihat bahwa nilai rata-rata pengetahuan pencemaran lingkungan lebih besar dari nilai KKM hal ini menunjukkan bahwa nilai pengetahuan pencemaran lingkungan sudah memenuhi syarat kriteria ketuntasan minimal (KKM).

Untuk mengetahui ada atau tidaknya pemgaruh pembelajaran pengetahuan pencemaran lingkungan secara online terhadap sikap peduli pada heritage TNBBS peserta didik maka dilakukan pengujian hipotesis dengan uji One Way Anova. Sebelum melakukan uji hipotesis One-Way Anova dilakukan terlebih dahulu uji normalitas dan uji homogenitas. Berdasarkan hasil yang diperoleh uji normalitas memperoleh angka signifikasi 0,504 > 0,05 dengan keputusan $\mathrm{H}_{0}$ diterima dan $\mathrm{H}_{1}$ ditolak yang berarti bahwa data yang berasal dari nilai pengetahuan pencemaran lingkungan dan sikap peduli pada heritage TNBBS berdistribusi normal. Sedangkan hasil yang diperoleh dari uji homgenitas sebesar 0,062 > 0,05 dengan keputusan $\mathrm{H}_{0}$ diterima dan $\mathrm{H}_{1}$ ditolak yang 
artinya variabel tersebut bersifat homogen. Adapun hasil uji one-way anova adalah sebagai berikut:

Tabel 2. Hasil Uji One-Way Anova Pengaruh Pembelajaran Pengetahuan Pencemaran Lingkungan Secara Online Terhadap Sikap Peduli Pada Heritage TNBBS

\begin{tabular}{l|r|r|r|r}
\hline \multicolumn{5}{c}{ One-Way Anova Test } \\
\hline Between & \multicolumn{1}{c}{ Df } & Mean Square & F & \multicolumn{1}{c}{ Sig. } \\
Groups & 19 & 229.809 & 2.541 & .011 \\
$\begin{array}{l}\text { Within } \\
\text { Groups } \\
\text { Total }\end{array}$ & 30 & 90.421 & & \\
\hline
\end{tabular}

Berdasarkan Tabel 2 diketahui nilai signifikasi sebesar 0,011. Nilai hasil Sig menunjukkan $\mathrm{H}_{1}$ diterima dan $\mathrm{H}_{0}$ ditolak. Hal ini juga sesuai dari nilai $\mathrm{F}_{\text {hitung }}$ sebesar 2,541 sedangkan nilai $F_{\text {tabel }}$ sebesar 1,95 dengan taraf 5\% artinya $F_{\text {hitung }}>F_{\text {tabel }}$ maka hal ini menunjukkan bahwa pembelajaran pengetahuan pencemaran lingkungan secara online berpengaruh terhadap sikap peduli pada heritage TNBBS.

Pada penelitian ini, guru menggunakan metode pembelajaran online pada masingmasing kelas dengan menggunakan aplikasi whatsapp group dan googlefrom. Guru menggunakan aplikasi tersebut untuk memberikan penugasan, diskusi online, dan kuis. Pemilihan dan penggunaan metode belajar yang baik sangat mempengaruhi proses pembelajaran sehingga dapat mencapai tujuan yang diinginkanya. Hal ini sesuai dengan Indah (2012: 11) yang menyatakan bahwa pembelajaran adalah proses interaksi peserta didik dan sumber belajar pada suatu lingkungan belajar. Pembelajaran merupakan bantuan yang diberikan pendidik agar dapat terjadi proses perolehan ilmu dan pengetahuan, penguasaan kemahiran dan tabiat, serta pembentukan sikap dan kepercayaan pada peserta didik. Hal ini juga sesuai dengan Riyanto dan Prasojo (2011: 207) yang menyatakan bahwa e-learning (pembelajaran online) adalah pembelajaran online berbasis internet dan internet yang membutuhkan sebuah media untuk dapat menampilkan materi-materi khusus dan pertanyaan-pertanyaan dan juga membutuhkan fasilitas komunikasi untuk dapat saling bertukar informasi antar peserta dengan pengajar.

Hasil uji hipotesis pada Tabel 2 menunjukkan bahwa pembelajaran pengetahuan pencemaran lingkungan secara online berpengaruh signifikan terhadap sikap peduli pada heritage TNBBS. Penelitian terdahulu yang dilakukan oleh Raharjo dan Santi (2020) menunjukkan bahwa adanya pengaruh pengetahuan pengelolaan sampah di sekolah terhadap sikap peduli lingkungan siswa di SDN Batan Indah. Hal ini juga didukung dengan hasil uji hipotesis (Tabel 1) yang menunjukkan bahwa rata-rata nilai data nilai pengetahuan pencemaran lingkungan memiliki rata-rata nilai sebesar 78 dengan kriteria baik dan hasil data nilai sikap peduli pada heritage TNBBS memiliki rata-rata nilai sebesar 83,31 dengan kriteria sangat baik.

Hal ini sesuai dengan The Kwonledge Triangle dimana proses pendidikan berkaitan dengan pengetahuan dan inovasi (Surbakti, 2015: 2). Inovasi disini adalah bidang sosial yang salah satunya adalah sikap peduli pada heritage TNBBS yang berarti jika dikaitan dengan penelitian ini adalah pendidikan (pembelajaran online) sangat berkaitan erat dengan pengetahuan dan inovasi (sikap sosial). Hal juga ini sejalan dengan pernyataan Woolfolk (1993: 239) yang menyatakan bahwa pengetahuan sebagai 
hasil kegiatan belajar, lebih dari sekedar produk akhir dari pembelajaran sebelumnya tetapi juga menjadi pedoman pembelajaran baru. Pernyataan tersebut menunjukkan bahwa manusia memperoleh pengetahuan melalui kegiatan belajar, dan pengetahuan yang telah dimiliki seseorang menjadi pedoman dalam mempelajari pengetahuan baru. Hal ini berarti bahwa terdapat kaitan antara pengetahuan yang satu dengan pengetahuan lainnya, dan saling melengkapi. Pengetahuan lainnya pada penelitian ini diartikan sebagai sikap dimana pengetahuan dan sikap memiliki hubungan yang saling berkaitan.

Hal ini juga sesuai dengan Krech dan Crutchfiel dalam Kodir (2016: 56) yang menyatakan bahwa sikap sebagai organisasi yang bersifat menetap dari proses motivasional, emosional, perseptual, dan kognitif mengenai aspek dunia individu. Hal ini berarti bahwa sikap seseorang yang ditunjukkan berasal dari berbagai proses salah satunya adalah proses kognitif yang telah di dapatnya. Proses kognitif pada penelitian ini adalah pengetahuan pencemaran lingkungan yang telah didapatkannya. Pada dasarnya metode pembelajaran secara online mengedepankan pemahaman dan pengetahuan peserta didik. Jika pengetahuan telah diperoleh oleh peserta didik maka sikap peserta didik juga akan terbentuk.

Dimensi Sikap Peduli Pada Heritage TNBBS. Untuk mengetahui dimensi mana yang paling dikuasai peserta didik untuk meningkatkan sikap peduli heritage TNBBS dapat dilihat pada Tabel 3.

Tabel 3. Hasil Nilai Sikap Peduli Pada Heritage Berdasarkan Dimensi Sikap Peduli

\begin{tabular}{c|c|c|c}
\hline No. & $\begin{array}{c}\text { Dimensi Sikap Peduli } \\
\text { Pada Heritage }\end{array}$ & $\begin{array}{c}\text { Jumlah } \\
\text { Total }\end{array}$ & Persentase (\%) \\
\hline $\mathbf{1}$ & Afeksi & 1769 & $35,38 \%$ \\
\hline $\mathbf{2}$ & Kognisi & 1538 & $30,76 \%$ \\
\hline $\mathbf{3}$ & Konasi & 1693 & $33,86 \%$ \\
\hline \multicolumn{3}{|c|}{} & $100 \%$ \\
\hline
\end{tabular}

Hasil rata-rata nilai sikap peduli pada heritage berdasarkan dimensi sikap peduli (Tabel 3) menunjukkan bahwa nilai dimensi yang paling tinggi yaitu pada dimensi "afeksi" dengan jumlah total 1769 dan nilai persentase 35,38\% artinya dimensi yang paling dikuasai peserta didik dalam meningkatkan sikap peduli pada heritage TNBBS adalah dimensi "afeksi". Sikap afeksi adalah sikap yang berkenaan dengan perasaan dalam menanggapi suatu objek. Hal ini artinya peserta didik memiliki perasaan untuk menjaga dan melindungi TNBBS karena peserta didik menyadari bahwa TNBBS merupakan suatu warisan yang sangat penting bagi kehidupan makhluk hidup dan harus dijaga kelestariannya. Sikap merupakan suatu keadaan internal (internal state) yang mempengaruhi pilihan tindakan individu terhadap objek, orang, atau kejadian tertentu.

Sikap peduli lingkungan merupakan sikap dan perilaku yang diharapkan mampu meningkatkan kesadaran masyarakat akan pentingnya kelestarian lingkungan khususnya pada heritage TNBBS. Hal tersebut sesuai dengan pernyataan Soetarno (1994) yang menyatakan sikap adalah pandangan atau perasaan yang disertai kecenderungan untuk bertindak terhadap objek tertentu. Sikap senantiasa diarahkan kepada sesuatu artinya tidak ada sikap tanpa objek. Sikap diarahkan kepada benda-benda, orang, peristiwa, pandangan, lembaga, norma dan lain-lain. Hal ini juga sesuai dengan Azwar (2013) menyatakan bahwa sikap terdiri terdiri dari beberapa tingkatan, yaitu tingkatan menerima (receiving), artinya bahwa orang atau subjek mau memperhatikan stimulus atau objek yang diberikan. Selanjutnya tingkat merespon (responding) artinya bahwa 
orang akan memberi jawaban bila ditanya atau mengerjakan/menyelesaikan tugas yang diberikan. Tingkatan menghargai (valuing) artinya bahwa orang mau mengajak orang lain untuk mendiskusikan atau mengerjakan sesuatu hal. Sedangkan tingkatan terakhir adalah bertanggung jawab (responsible) sebagai tingkatan sikap yang paling tinggi dimana orang bertanggung jawab atas suatu hal yang sudah dipilihnya dengan segala resiko.

Sejalan dengan penjelasan diatas, pembelajaran pengetahuan pencemaran lingkungan secara online dapat meningkatkan sikap afeksi bagi peserta didik karena pada pembelajaran secara online peserta didik menggunakan media komunikasi seperti handphone, komputer, leptop atau sebagainya untuk menunjang proses pembelajaran dan mendapatkan informasi secara online mengenai heritage TNBBS serta mendapatkan pengetahuan baru sehingga terbentuklah sikap terhadap suatu hal. Hal ini sesuai dengan Pertiwi (2017: 12-13) yang menyatakan bahwa informasi yang diperoleh seorang individu melalui media massa (media komunikasi) tersebut akan memberikan landasan kognitif baru bagi terbentuknya sikap terhadap suatu hal, dimana pesan-pesan sugestif informasi tersebut apabila cukup kuat akan memberi dasar afektif dalam menilai suatu hal sehingga terbentuklah arah sikap tertentu.

\section{SIMPULAN}

Adapun simpulan yang diperoleh berdasarkan hasil penelitian yaitu pertama, ada pengaruh yang signifikan penggunaan pembelajaran pengetahuan pencemaran lingkungan secara online terhadap sikap peduli pada heritage TNBBS di SMP Negeri 1 Ulubelu.kedua, dimensi yang paling dikuasai peserta didik dalam meningkatkan sikap peduli pada heritage TNBBS adalah dimensi "Afeksi".

\section{DAFTAR RUJUKAN}

Azwar. (2013). Sikap Manusia: Teori dan Pengukurannya. Yogyakarta: Pustaka Pelajar.

Bilfaqih, Y dan Qomarudin, N. M. (2015). Esensi Pengembangan Pembelajaran Daring. Yogyakarta: Deepublish.

Deni. (2011). Analisis Perambahan Hutan Di Taman Nasional Bukit Barisan Selatan (Studi Kasus Desa Tirom Di Kecamatan Pematang Sawah Kabupaten Tanggamus). Jurnal Ilmu Kehutanan, 5 (1): 9-20.

Entas, D., dan Widiastiti, I., P. (2018). Kawasan Heritage Jalan Gajah Mada Sebagai Upaya Pelestarian Kawasan Kota Tua Denpasar Bali. Jurnal Industri Pariwisata, 1 (1): 13-19.

Fitria, F. (2016). Hubungan Antara Pengetahuan dengan Sikap Siswa SMA Negeri di Kota Banda Aceh Terhadap Pemanasan Global. Jurnal Pendidikan. FKIP Unsyiah. Banda Aceh. (Online), (http://etd.unsyiah.ac.id/index.php?p=show _detail\&id=24825, diakses pada 25 November 2019).

Howard, P. (2003). Heritage, Management, Interpretation, Identity. New York: Lexington Avenue.

Kellstedt, P.M. (2008). Personal Efficacy, the Information Environment and Attitudes toward Global Warming and Climate Change in the United State. Journal for the Scientific Study, 28 (1): 113-126.

Kodir, A. (2016). Pengaruh Model Pembelajaran IPA Berbasis Lingkungan dan Kemampuan Awal terhadap Peningkatan Pengetahuan dan Sikap Peserta 
Didik di MTs Kota Kendari. Tesis tidak diterbitkan. Makasar: Universitas Makasar.

Krech, et al. (1982). Individual in Society. Cetakan ke-4. Auckland: McGraw-Hill.

Masruroh. (2018). Membentuk Karakter Peduli Lingkungan Dengan Pendidikan. Jurnal Pendidikan Geografi, 18 (2): 130-134.

Pertiwi, R. (2017). Pengaruh Siswa Terhadap Keaktifan Belajar Kompetensi Pembuat Saku Tempel Mata Pelajaran Dasar Teknologi Menjahit Kelas X Jurusan Tata Busana SMKN 6 Yogyakarta. Skripsi tidak diterbitkan. Yogyakarta: Universitas Negeri Yogyakarta.

Pertiwi, O. P., (2019). Perbandingan Pengetahuan Biodiversitas dan Sikap Peduli Lingkungan Antara Siswa di Kawasan Konservaso Taman Nasional Way Kambas Dengan Siswa Di Perkotaan. Skripsi tidak diterbitkan. Bandar Lampung: Universitas Lampung.

Riyanto dan Prasojo, L. D. (2011). Teknologi Informasi Pendidikan Membahas Materi Dasar Teknologi Yang Wajib Dikuasai Pemula TI. Yogyakarta: Gava Media.

Soetarno. (1994). Sikap, Pengertian, Definisi, dan Faktor yang Mempengaruhi. (Online), (http://www.duniapsikologi.com/sikap-pengertian-definisi-danfaktoryang-mempengaruhi/, diakses pada tanggal 17 Juli 2020.)

Sugiyono. (2012). Metode Penelitian Pendidikan Pendekatan Kuantitatif, Kualitatif, dan R\&D. Bandung: Alfabeta.

Surbakti, A. (2015). Pendidikan Kependudukan dan Lingkungan Hidup. Yogyakarta: Graha Ilmu.

Unesco. (1972). Convention Concerning The Protection Of The World Cultural and Heritage. Paris: UNESCO.

Woolfolk. (1993). Educational Psychology. Jakarta: Ally dan Bacon. 